Received $\quad 19.10 .2018$

Reviewed $\quad 01.04 .2019$

Accepted 28.05.2019

A - study design

B - data collection

C - statistical analysis

D - data interpretation

$\mathbf{E}$ - manuscript preparation

$\mathbf{F}$ - literature search

\title{
Monitoring of selected fertilizer nutrients in surface waters and soils of agricultural land in the river valley in Central Poland
}

\author{
Irena BURZYŃSKA ${ }^{\mathrm{ABCDEF} \otimes}$
}

Institute of Technology and Life Sciences, Falenty, al. Hrabska 3, 05-090 Raszyn, Poland; e-mail: i.burzynska@itp.edu.pl

For citation: Burzyńska I. 2019. Monitoring of selected fertilizer nutrients in surface waters and soils of agricultural land in the river valley in Central Poland. Journal of Water and Land Development. No. 43 (X-XII) p. 41-48. DOI: 10.2478/jwld-20190061.

\begin{abstract}
The aim of the study was to assess the content of soluble forms of fertilizer nutrients $(\mathrm{N}, \mathrm{P}, \mathrm{K})$ in the cultivated soil layer up to $20 \mathrm{~cm}$ deep from agricultural land in the river valley, and the concentration of these nutrients in the surface waters of the Raszynka River.

In the years 2016-2017, the surface water samples from the Raszynka Rriver (17 points) and soil (19 points) were collected from agricultural areas near the Raszynka River.

The surface water samples were collected once a month during the March-October 2016-2017. The contents of nitrogen $\left(\mathrm{N}_{\text {tot }}, \mathrm{NO}_{3}-\mathrm{N}\right.$ and $\left.\mathrm{NH}_{4}-\mathrm{N}\right)$, phosphorus $\left(\mathrm{P}_{\text {tot }}, \mathrm{PO}_{4}-\mathrm{P}\right)$, total organic carbon (TOC and $\mathrm{K}$ and $\mathrm{Ca}$ ) in soils and in waters were determined in the sample solutions.

It was shown that river water was of low quality due to the high concentration of nitrogen and phosphorus and electrical conductivity $(E C)$. The most polluted were the waters of the lower section of the river located in the vicinity of arable land and agricultural built-up areas. The soluble forms of nutrients content in the cultivated soil layer was varied depending on the kind of nutrient, way of agricultural land use, and the term of soil sampling. The content of dissolved $\mathrm{P}$ forms in the soil was the highest in autumn on arable lands after harvesting of vegetables (GO-W: $10.24 \mathrm{mg} \mathrm{P}_{\text {tot }} \cdot \mathrm{kg}^{-1}$ in D.M.) and this component may migrate with surface runoff and increase the risk of surface water eutrophication.
\end{abstract}

Key words: agricultural catchment, cultivated soil layer, nutrients, surface waters, the river valley

\section{INTRODUCTION}

Agricultural pollution is mainly of an area nature and concerns the loss of nutrients from mineral and organic fertilizers used on arable land and erosion processes affecting the migration of nutrients in the environment [ZAK et al. 2018; ZBIERSKA (ed.) 2002]. The way of using agricultural land may affect on rate of erosion, the soil moisture, the availability nutrients, return of biomass to the soil and the soil structure [PRIJONO et al. 2015; SURYOPUTRO et al. 2018]. According to studies by SAVCI [2012] from a dose of nitrogen fertilizer introduced into the soil only about $50 \%$ take plants, $25 \%$ is immobilized in soil, $20 \%$ is gas loss and 5\% is leaching.

Intensification of agricultural production against the background of increasing climate changes may increase the migration of nutrients to the surface waters [DODDS 2007; JEPPESEN et al. 2010; WOLF et al. 2005]. The problem of eutrophication of surface waters concern about $40 \%$ of the world's waters and it is closely related to the nutrients concentration, especially nitrogen and phosphorus [GALCZYŃSKA, BUŚKO 2016; GARG, GARG 2002; JEPPSEN et al. 1999; LIU et al. 2008; WWAP 2009]. Excessive enrichment of surface waters with nutrients degrades aquatic ecosystems and impedes the economic use of waters for agriculture and other purposes. Nutrients from agricultural sources (nitrogen and phosphorus) from the Poland territory are discharged into the Baltic Sea by the Vistula River (54\% of waters) and the Odra River (34\% of waters) [IGRAS, PASTUSZAK (ed.) 2009].

The aim of the study was to evaluate the content of selected mineral nutrients, i.e. $\mathrm{N}, \mathrm{P}, \mathrm{K}, \mathrm{Mg}, \mathrm{Ca}$ in the culti- 
vated soil layer from soils agricultural used in the river valley in the aspect of the surface water quality of the river in the agricultural catchment.

\section{MATERIALS AND METHODS}

The studies carried out in the agricultural catchment of the Raszynka River (N 52'08'34.1 E 020'56'09.5), which is the right tributary of the Utrata River. The Raszynka River is a small lowland river in Center Poland with a length of $17.40 \mathrm{~km}$ and flowing through two districts i.e. Piaseczno and Pruszków in the Masovia Province. The source of the river is taking its origin in the commune of Lesznowola, and in the final section of the Raszynka River it flows into the Utrata River.

The river catchment covers an area of $75.9 \mathrm{~km}^{2}$ and is situated on the border between the mesoregions of the Łowicko-Błońska Plain (the lower part of the basin) and the Warsaw Plain (middle and upper part) [CZARNECKA (ed.) 2003]. In the river valley there are mostly black cumulative soils and brown soils according to the classification PTG 2011 [MARCINEK, KOMISAREK (ed.) 2011].

The research area is located in the third climate zone of Poland and is characterised by a vegetation period of 210-220 days and low annual precipitation of 450$500 \mathrm{~mm}$.

The catchment had agricultural specifics, and arable lands constitute $65.5 \%$, built-up areas $24.0 \%$, forests $11.5 \%$, and soils $2.5 \%$ of the land development structure. The direct vicinity of the city of Warsaw boosts high demand for agricultural products, fostering production of vegetables in the municipalities neighbouring the Warsaw metropolitan area.

In 2016-2017 the surface water samples were taken from the Raszynka River (17 points) and the soil (19 points) samples were taken from the land situated near this river. Surface water samples were collected once a month during March-October 2016-2017 period in accordance with PN-EN 25667-2: 1999. Soil samples from the cultivated soil layer up to $20 \mathrm{~cm}$ deep were collected twice a year, i.e. early spring (March) and autumn (October) 2016-2017. Soil samples were taken from agricultural land located in the vicinity of the river, i.e. arable land (GO-W and $\mathrm{GO}-\mathrm{K}$ ), grassland (UZ-P and UZ-N), and wooded areas with alder (NU-L). $\mathrm{pH}$ value was measured in the solution from the soil (in $0.01 \mathrm{M} \mathrm{CaCl}_{2}$ ) and in surface waters - potentiometry using a $\mathrm{pH}$ meter, according to PN-EN ISO 10390:1997 and PN-EN ISO 10523:2012. Determination of electrical conductivity $(E C)$ of the surface waters tested was measured by the conductomer method according to PN-EN 27888: 1999.

Soil samples were mineralized in concentrated mineral acids (perchloric and nitric) according to the procedure $\mathrm{PB} / 31 / 02 / 2014$ - for $\mathrm{K}_{\text {tot }}, \mathrm{Ca}_{\text {tot }}, \mathrm{P}_{\text {tot }}$ and in sulfuric acid according to $\mathrm{PB} / 31 / 03 / 2014$ for $\mathrm{N}_{\text {tot }}$. The total organic carbon (TOC) content in the soil samples was made using the Tiurn's method [SAPEK, SAPEK 1997]. Labile forms of nutrient such as: $\mathrm{N}, \mathrm{P}, \mathrm{K}, \mathrm{Ca}$ were determined after soil extraction with water solution (1:5) in accordance with PN-EN 13652: 2002.

Physicochemical measurements were made in surface water samples.

The content of nitrogen $\left(\mathrm{N}_{\text {tot }}, \mathrm{NO}_{3}-\mathrm{N}\right.$ and $\left.\mathrm{NH}_{4}-\mathrm{N}\right)$, phosphorus $\left(\mathrm{P}_{\text {tot }}, \mathrm{PO}_{4}-\mathrm{P}\right)$ and TOC in solutions were determined using the automated method with segmented flux flow (SFA) in accordance with the Skalar methods and PN-EN ISO 13395:2001; PN-EN ISO 6878:2006; PN-EN 1484:1999. The content of $\mathrm{K}$ and $\mathrm{Ca}$ in solutions measured by atomic flame spectrophotometry [PN-ISO 9964-2:/Ak: 1997]. Total organic carbon (TOC) content in the soil was determined by the manual colorimetric method [SAPEK, SAPEK 1997].

All chemical analyses were performed at the Research Laboratory of Environmental Chemistry in the Institute of Technology and Life Sciences at Falenty.

Table 1. Description of the surface waters and soils sampling from the agricultural land in the vicinity of the Raszynka River

\begin{tabular}{|c|c|c|c|c|c|c|}
\hline Part of the river & $\mathrm{Km}$ of the river & Water sampling point & Soil sampling point & Locality & Community & Land use \\
\hline Lower & $0.0-4.50$ & $\begin{array}{l}\mathrm{R}-1 \\
\mathrm{R}-2 \\
\mathrm{R}-3 \\
\mathrm{R}-4 \\
\mathrm{R}-5 \\
\mathrm{R}-6\end{array}$ & $\begin{array}{l}\text { G-1 and G-2 } \\
\text { G-3 } \\
\text { G-4 } \\
\text { G-5 } \\
\text { G-6 }\end{array}$ & $\begin{array}{l}\text { Podolszyn Nowy } \\
\text { Łady } \\
\text { Dawidy B } \\
\text { Dawidy } \\
\text { Dawidy } \\
\text { - }\end{array}$ & $\begin{array}{l}\text { Lesznowola } \\
\text { Raszyn } \\
\text { Raszyn } \\
\text { Raszyn } \\
\text { Raszyn }\end{array}$ & $\begin{array}{l}\text { NU-L } \\
\text { NU-L } \\
\text { GO-W } \\
\text { UZ-P } \\
\text { GO-W } \\
-\end{array}$ \\
\hline Middle & $4.60-11.0$ & $\begin{array}{l}\text { R-7 } \\
\text { R-8 } \\
\text { R-9 } \\
\text { R-10 } \\
\text { R-11 } \\
\text { R-12 } \\
\text { R-13 }\end{array}$ & $\begin{array}{l}\text { G-7 } \\
\text { G-8 } \\
\text { G-9 } \\
\text { G-10 } \\
\text { G-11 } \\
\text { G-12 } \\
\text { G-13 } \\
\text { G-14 } \\
\text { G-15 }\end{array}$ & $\begin{array}{l}\text { Jaworowa } \\
\text { Jaworowa } \\
\text { Falenty, al. Hrabska } \\
\text { Falenty, GOŚ } \\
\text { Falenty, before GOŚ Raszyn } \\
\text { Raszyn ditch Opaczewski } \\
\text { Raszyn } \\
\text { Raszyn } \\
\text { Raszyn }\end{array}$ & $\begin{array}{l}\text { Raszyn } \\
\text { Raszyn } \\
\text { Raszyn } \\
\text { Raszyn } \\
\text { Raszyn } \\
\text { Raszyn } \\
\text { Raszyn } \\
\text { Raszyn } \\
\text { Raszyn }\end{array}$ & $\begin{array}{l}\text { UZ-P } \\
\text { UZ-P } \\
\text { NU-N } \\
\text { GO-W } \\
\text { UZ-P } \\
\text { GO-W } \\
\text { NU-N } \\
\text { NU-N } \\
\text { NU-N }\end{array}$ \\
\hline Upper & $11.5-17.0$ & $\begin{array}{l}\text { R-14 } \\
\text { R-15 } \\
\text { R-16 } \\
\text { R-17 }\end{array}$ & \begin{tabular}{l|} 
G-16 \\
G-17 \\
G-18 \\
G-19
\end{tabular} & $\begin{array}{l}\text { Michałowie Wieś } \\
\text { Michałowie Wieś } \\
\text { Pęcice } \\
\text { Pęcice }\end{array}$ & $\begin{array}{l}\text { Michałowice } \\
\text { Michałowice } \\
\text { Michałowice } \\
\text { Michałowice }\end{array}$ & $\begin{array}{l}\text { NU-L } \\
\text { GO-K } \\
\text { UZ-N } \\
\text { UZ-N }\end{array}$ \\
\hline
\end{tabular}

Explanations: GOŚ = Communal Sewage Treatment Plant, GO-W = arable land, vegetable grown; GO-K = arable land, maize; UZ-P = production meadow; UZ-N = natural meadow; NU-L = alder forest.

Source: own elaboration. 


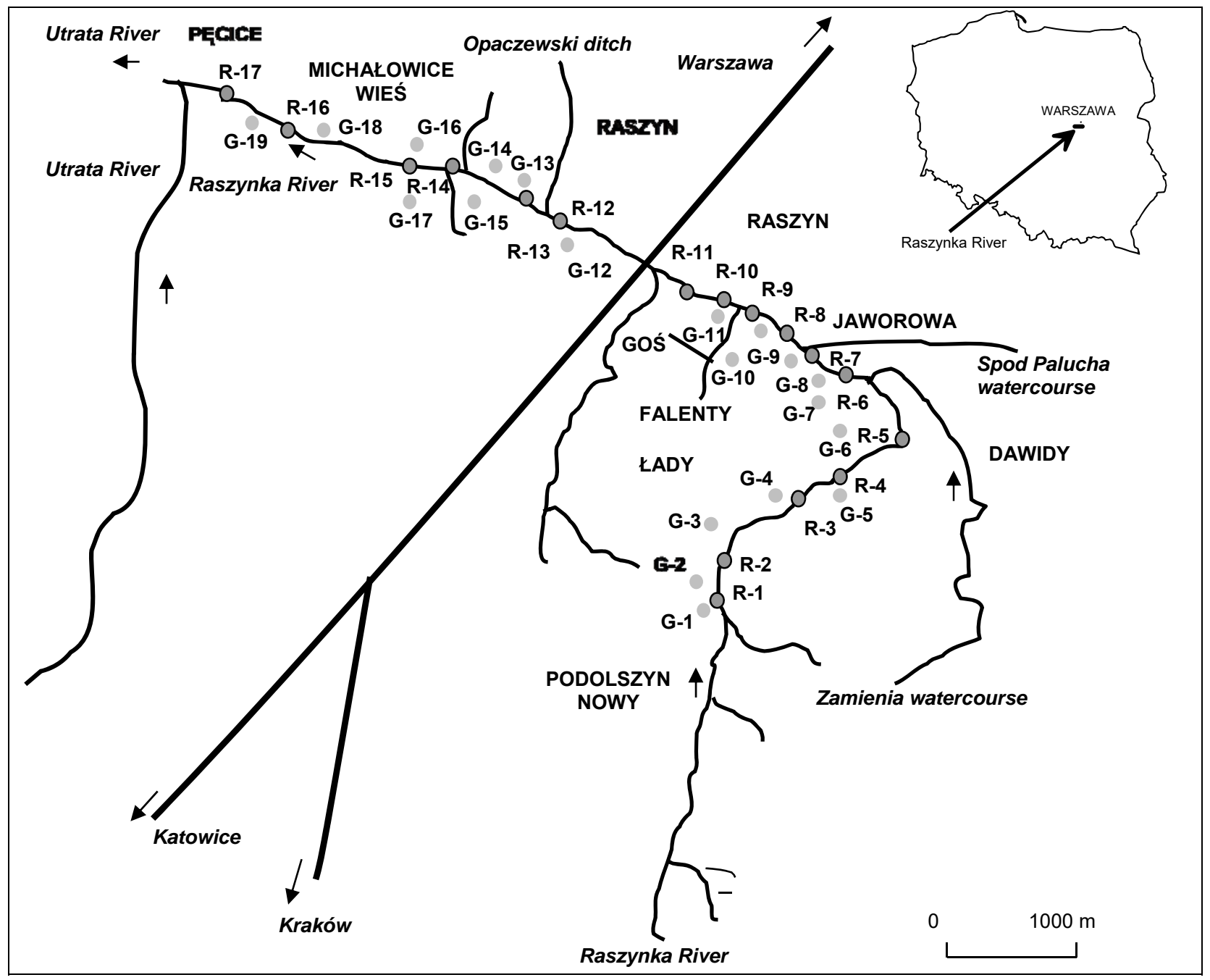

Fig. 1. Measuring points in the catchment of the Raszynka River; source: own elaboration

\section{STATISTICAL ANALYSIS}

The obtained results were processed statistically using Statistica 7.0. In order to evaluate the physico-chemical parameters in the Raszynka River, a one-way ANOVA variance analysis was performed for the mean values. The significance of the differences between the mean values was checked with the Tukey's HSD (honest significant difference test) level of $p=0.05$.

\section{RESULTS AND DISCUSSION}

\section{SELECTED PHYSICOCHEMICAL PARAMETERS OF THE RASZYNKA RIVER WATERS}

The $\mathrm{pH}$ of waters from the Raszynka River were in the range $6.89-9.04 \mathrm{pH}$ at the average $\mathrm{pH}$ value of $\mathrm{pH} 8.00$ in the years 2017-2018. The obtained value was on the border of the acceptable $\mathrm{pH}$ range for the lowland sandy and clay river [Rozporządzenie... 2016]. There were no significant differences between the average $\mathrm{pH}$ values between parts of the river (Tab. 2).

River waters were excessively contaminated with mineral nutrients, because the average value of electrical con- ductivity (EC) was $753 \mu \mathrm{S} \cdot \mathrm{cm}^{-1}$ and exceeded the acceptable range for the 2 nd quality class for the surface waters [Rozporządzenie... 2016]. A significant variation of the $E C$ values of these surface waters $\left(80-1149 \mu \mathrm{S} \cdot \mathrm{cm}^{-1}\right)$.

The range of nitrate nitrogen concentration in the Raszynka River water was varied from 0.09 to 7.55 $\mathrm{mg} \mathrm{N}-\mathrm{NO}_{3} \cdot \mathrm{dm}^{-3}$. The average concentration of these nutrients in parts of the Raszynka River was even 1.5-2 times higher than the limit values for the 2 nd quality class for the surface waters [Rozporządzenie... 2016]. The most polluted with this nutrient was water taken from the upper section of the Raszynka River $(0.0-4.5 \mathrm{~km})$ near that, there were arable lands under cultivation of vegetables (Tab. 2). The concentration of $\mathrm{N}-\mathrm{NO}_{3}$ in the surface waters from the lower section of the river $(11.5-17.0 \mathrm{~km})$, although it was outside the acceptable range, it was much smaller than in the upper part of this river. In the structure of land use in the lower part of the river, natural meadows dominated without economic use. The way land use was probably had an effect on the partial reduction of $\mathrm{N}-\mathrm{NO}_{3}$ concentration in river waters. A similar tendency of lower water pollution in the lower part of the Raszynka River was also observed by PAWŁAT-ZAWRZYKRAJ [2003] and DĄBKOWSKI, PAWLAT-ZAWRZYKRAJ [2003]. 
Table 2. Selected physicochemical parameters in the waters of the Raszynka River in 2016-2017

\begin{tabular}{|c|c|c|c|c|c|c|c|c|c|}
\hline \multirow{2}{*}{$\begin{array}{c}\text { Part } \\
\text { of the river }\end{array}$} & \multirow{2}{*}{ Value } & \multirow{2}{*}{$\mathrm{pH}$} & \multirow{2}{*}{$\begin{array}{c}E C \\
\mu \mathrm{S} \cdot \mathrm{cm}^{-1}\end{array}$} & $\mathrm{~N}-\mathrm{NO}_{3}$ & $\mathrm{~N}-\mathrm{NH}_{4}$ & $\mathrm{P}-\mathrm{PO}_{4}$ & $\mathrm{~K}$ & $\mathrm{Ca}$ & OWO \\
\hline & & & & \multicolumn{6}{|c|}{$\mathrm{mg} \cdot \mathrm{dm}^{-3}$} \\
\hline \multirow{3}{*}{$\begin{array}{l}\text { Lower } \\
(n=40)\end{array}$} & mean & $8.02 \mathrm{a}$ & $792 \mathrm{a}$ & $5.17 \mathrm{a}$ & $4.66 \mathrm{a}$ & $0.49 \mathrm{a}$ & $13.68 \mathrm{a}$ & $65.32 \mathrm{a}$ & $7.75 \mathrm{a}$ \\
\hline & $\min -\max$ & $7.24-9.01$ & $80-1053$ & $0.29-11.23$ & $0.02-28.18$ & $0.09-0.83$ & $6.65-33.75$ & $19.50-108.30$ & $4.18-30.92$ \\
\hline & $S D$ & 0.34 & 179 & 3.24 & 8.74 & 0.21 & 6.62 & 24.85 & 4.85 \\
\hline \multirow{3}{*}{$\begin{array}{l}\text { Middle } \\
(n=38)\end{array}$} & mean & $7.96 \mathrm{a}$ & $723 \mathrm{a}$ & $4.24 \mathrm{ab}$ & $1.08 \mathrm{~b}$ & $0.38 \mathrm{a}$ & $15.25 \mathrm{a}$ & $53.50 \mathrm{a}$ & $7.27 \mathrm{a}$ \\
\hline & $\min -\max$ & $6.83-9.04$ & 149-1149 & $0.09-7.55$ & $0.05-13.72$ & $0.07-0.78$ & $6.62-38.79$ & $10.66-99.81$ & $3.35-16.00$ \\
\hline & $S D$ & 0.60 & 179 & 2.76 & 2.76 & 0.20 & 7.62 & 23.66 & 2.28 \\
\hline \multirow{3}{*}{$\begin{array}{c}\text { Upper } \\
(n=22)\end{array}$} & mean & $7.99 \mathrm{a}$ & $737 \mathrm{a}$ & $3.20 \mathrm{~b}$ & $0.39 \mathrm{~b}$ & $0.34 \mathrm{a}$ & $11.22 \mathrm{a}$ & $50.92 \mathrm{a}$ & $7.14 \mathrm{a}$ \\
\hline & $\min -\max$ & $7.14-8.96$ & $498-974$ & $1.38-5.58$ & $0.07-2.11$ & $0.14-0.66$ & $8.34-18.91$ & $17.94-80.81$ & $5.86-9.74$ \\
\hline & $S D$ & 0.50 & 136 & 1.02 & 0.49 & 0.15 & 3.18 & 16.00 & 1.16 \\
\hline \multirow{3}{*}{$\begin{array}{c}\text { All } \\
(n=100)\end{array}$} & mean & 8.00 & 753 & 4.38 & 2.36 & 0.41 & 13.74 & 57.66 & 7.43 \\
\hline & $\min -\max$ & $6.83-9.04$ & $80-1149$ & $0.09-7.55$ & $0.02-28.18$ & $0.07-0.83$ & $6.62-38.79$ & $10.66-108.30$ & $3.35-30.92$ \\
\hline & $S D$ & 0.54 & 172 & 2.54 & 6.05 & 0.20 & 6.59 & 23.48 & 3.40 \\
\hline
\end{tabular}

Explanations: $E C=$ electrical conductivity; $S D=$ standard deviation; TOC = total organic carbon; $n=$ numbers; a, $\mathrm{b}=$ homogenous groups.

Source: own study.

The Raszynka River waters were also excessively contaminated with ammonium nitrogen (0.02-218.18 $\mathrm{mg} \mathrm{N}-\mathrm{NH}_{4} \cdot \mathrm{dm}^{-3}$ ), and the average concentration of this nutrient depended on the river section. Surface waters from the upper part river were most polluted with ammonium nitrogen and average value of this nutrient was many times exceeded the acceptable range for surface waters [Rozporządzenie... 2016] (Tab. 2). Least of ammonium nitrate was in the lower part of river, and its average concentration was typical for 2 nd class quality of the surface waters. Ammonium ions in surface waters usually come from the biochemical decomposition of organic nitrogen compounds of plant or animal origin, they also formed in the nitrate reduction process. The source of ammonium ions may also be uncontrolled discharge of sewage from human settlements and industry [HERMANOWICZ et al. 1999].

Surface waters taking from the Raszynka River were of poor quality due to the phosphate phosphorus high concentration. The concentration of this nutrient was range 0.07 to $0.83 \mathrm{mg}$ of $\mathrm{PO}_{4}-\mathrm{P} \cdot \mathrm{dm}^{-3}$ and no significant differences were found between the average values in parts of this river (Tab. 2). Studies conducted by DĄBKOWSKI and PAWŁAT-ZAWRZYKRAJ [2003], PAWŁAT-ZAWRZYKRAJ
[2003] and BURZYŃSKA [2015; 2016], show that the waters taking agricultural origin from the Raszynka River were of poor quality due to nitrogen and phosphorus high concentration. The potassium and calcium concentrations in the surface waters were small $\left(<16.0 \mathrm{mg} \mathrm{K} \cdot \mathrm{dm}^{-3}\right.$ and $<70.0 \mathrm{mg}$ $\left.\mathrm{Ca} \cdot \mathrm{dm}^{-3}\right)$ and did not change in parts of the river.

The average concentration of organic substances expressed in total organic carbon in the river waters were low $\left(<8.00 \mathrm{mg}\right.$ TOC $\left.\cdot \mathrm{dm}^{-3}\right)$ and did not differ in individual parts of the river (Tab. 2).

\section{PH VALUE AND SELECTED NUTRIENTS CONTENTS IN AGRICULTURAL SOILS FROM THE RIVER VALLEY}

The total organic carbon (TOC) content in soils of agricultural land in the vicinity of the Raszynka River was varied in the range $11.4-145 \mathrm{~g} \mathrm{TOC} \cdot \mathrm{kg}^{-1}$ in D.M. The highest average content of this nutrient was found in soils taking from the natural meadows and the alder forest (623 $\mathrm{g}$ TOC $\cdot \mathrm{kg}^{-1}$ in D.M.). It's lowest content was obtained in arable land soils (GO-K: 20.5 and GO-W: $21.4 \mathrm{~g}$ TOC $\cdot \mathrm{kg}^{-1}$ in D.M.) - Table 3. The obtained results are confirmed by the studies GŁODOWSKA and GAŁĄZKA [2018] and ZBYTEK

Table 3. $\mathrm{pH}$ value and N, P, K, total organic carbon - TOC ( $\mathrm{g} \cdot \mathrm{kg}^{-1}$ in D.M.) content in the cultivated soil layer (to $20 \mathrm{~cm}$ depth) from agricultural land used in the vicinity of the Raszynka River in 2016-2017 $(n=40)$

\begin{tabular}{|c|c|c|c|c|c|c|c|}
\hline \multirow{3}{*}{ Land use category } & \multirow{3}{*}{ Value } & \multicolumn{6}{|c|}{ Parameters of the soil } \\
\hline & & \multirow{2}{*}{$\mathrm{pH}_{\mathrm{CaCl} 2}$} & TOC & $\mathrm{N}_{\text {tot }}$ & $\mathrm{P}_{\text {tot }}$ & $\mathrm{K}_{\text {tot }}$ & $\mathrm{Ca}_{\text {tot }}$ \\
\hline & & & \multicolumn{5}{|c|}{$\mathrm{g} \cdot \mathrm{kg}^{-1}$} \\
\hline Arable land, vegetable grown (GO-W) & $\begin{array}{c}\text { mean } \\
\text { min-max } \\
S D\end{array}$ & $\begin{array}{c}6.37 \\
6.01-6.78 \\
0.24 \\
\end{array}$ & $\begin{array}{c}21.4 \\
11.4-34.2 \\
0.85 \\
\end{array}$ & $\begin{array}{c}1.82 \\
1.03-2.25 \\
0.06 \\
\end{array}$ & $\begin{array}{c}0.79 \\
0.45-1.14 \\
0.03 \\
\end{array}$ & $\begin{array}{c}1.69 \\
1.20-2.50 \\
0.04 \\
\end{array}$ & $\begin{array}{c}3.50 \\
1.11-10.57 \\
0.25 \\
\end{array}$ \\
\hline Arable land, maize $(\mathrm{GO}-\mathrm{K})$ & $\begin{array}{c}\text { mean } \\
\min -\max \\
S D\end{array}$ & $\begin{array}{c}6.41 \\
6.35-6.49 \\
0.06 \\
\end{array}$ & $\begin{array}{c}20.7 \\
20.1-21.1 \\
0.05 \\
\end{array}$ & $\begin{array}{c}1.80 \\
1.59-1.19 \\
0.02 \\
\end{array}$ & $\begin{array}{c}0.84 \\
0.80-0.86 \\
0.01\end{array}$ & $\begin{array}{c}0.98 \\
0.70-1.26 \\
0.03\end{array}$ & $\begin{array}{c}2.86 \\
2.07-3.55 \\
0.70\end{array}$ \\
\hline Meadows of productively use (UZ-P) & $\begin{array}{c}\text { mean } \\
\text { min-max } \\
S D \\
\end{array}$ & $\begin{array}{c}6.77 \\
6.46-7.30 \\
0.26 \\
\end{array}$ & $\begin{array}{c}57.2 \\
19.5-145.0 \\
3.79 \\
\end{array}$ & $\begin{array}{c}2.95 \\
1.58-8.48 \\
0.20 \\
\end{array}$ & $\begin{array}{c}0.68 \\
0.33-1.69 \\
0.05 \\
\end{array}$ & $\begin{array}{c}1.19 \\
0.50-3.20 \\
0.08 \\
\end{array}$ & $\begin{array}{c}3.62 \\
1.14-9.85 \\
0.30 \\
\end{array}$ \\
\hline Natural meadows (UZ-N) & $\begin{array}{c}\text { mean } \\
\min -\max \\
S D\end{array}$ & $\begin{array}{c}6.36 \\
6.23-6.45 \\
0.08 \\
\end{array}$ & $\begin{array}{c}62.3 \\
48.1-97.20 \\
1.85 \\
\end{array}$ & $\begin{array}{c}3.61 \\
1.81-6.00 \\
0.15 \\
\end{array}$ & $\begin{array}{c}2.40 \\
1.39-4.00 \\
0.10 \\
\end{array}$ & $\begin{array}{c}1.00 \\
0.50-1.65 \\
0.04 \\
\end{array}$ & $\begin{array}{c}3.18 \\
1.18-5.54 \\
0.13 \\
\end{array}$ \\
\hline Alder forest (NU-L) & $\begin{array}{c}\text { mean } \\
\min -\max \\
S D\end{array}$ & $\begin{array}{c}6.25 \\
6.01-6.70 \\
0.30 \\
\end{array}$ & $\begin{array}{c}62.3 \\
26.6-110.1 \\
4.30\end{array}$ & $\begin{array}{c}5.45 \\
4.46-6.96 \\
0.13 \\
\end{array}$ & $\begin{array}{c}1.18 \\
1.10-1.31 \\
0.01 \\
\end{array}$ & $\begin{array}{c}1.40 \\
1.18-1.61 \\
0.01 \\
\end{array}$ & $\begin{array}{c}3.21 \\
2.58-3.75 \\
0.06 \\
\end{array}$ \\
\hline
\end{tabular}

Explanations: $n, S D$ as in Tab. 2.

Source: own study. 
and TALARCZYK [2012]. These authors showed that intensification of cultivation and fertilization, crops on arable lands, contributes to reducing crop residue and the soil organic matter (SOM) reduce the formation. These factors contribute to the reduction of the soil potential production and may lead to of the agricultural soils degradation.

Total nitrogen content in the soil layer up to $20 \mathrm{~cm}$ deep similar to TOC was varied in the range: $103-848 \mathrm{mg}$ $\mathrm{N}_{\text {tot }} \cdot \mathrm{kg}^{-1}$ in D.M. on the agricultural land with diversified use. The smallest average content of this nutrient was found on the arable land (180 mg $\mathrm{N}_{\text {tot }} \cdot \mathrm{kg}^{-1}$ in D.M.) and highest value was obtained under alder forest $(5.45 \mathrm{mg}$ $\mathrm{N}_{\text {tot }} \cdot \mathrm{kg}^{-1}$ D.M.).

The content of soluble forms of nutrients in the cultivated soil layer was varied depending on the kind of nutrient, way of agricultural land use, and the term of soil sampling (Fig. 2). The soils of arable land had a much lower content of the easily soluble form of nitrogen than the grassland and alder forest (Fig. 2). The most fertile of nitrate nitrogen was the soil from the alder forest in (107.82 mg N-NO ${ }_{3} \cdot \mathrm{kg}^{-1}$ D.M.) and meadows taking in the autumn (UZ-P; 89.95 and UZ-N; $80.53 \mathrm{mg} \mathrm{N}-\mathrm{NO}_{3} \cdot \mathrm{kg}^{-1}$ D.M.). However, ammonium nitrogen content in soils was significantly higher in the autumn than in the spring. The ob-

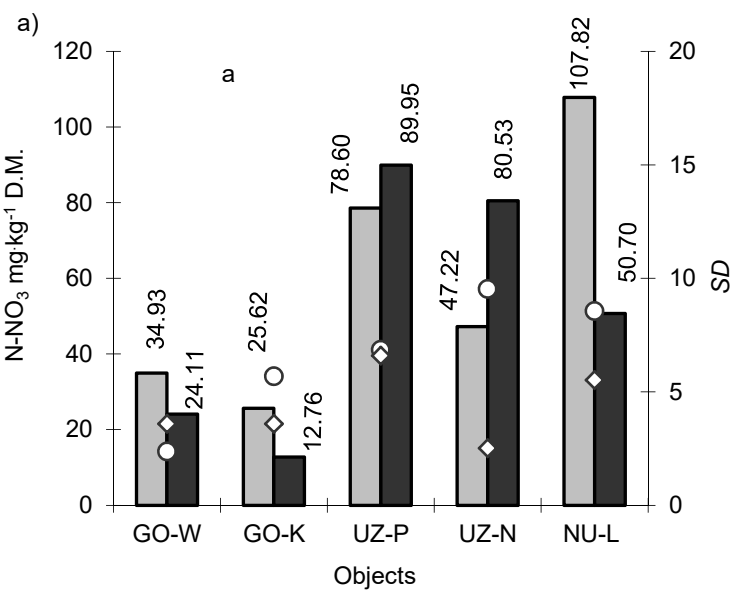

口III-2017 Mean aX-2017 Mean Olll-2017 SD $\diamond X-2017$ SD

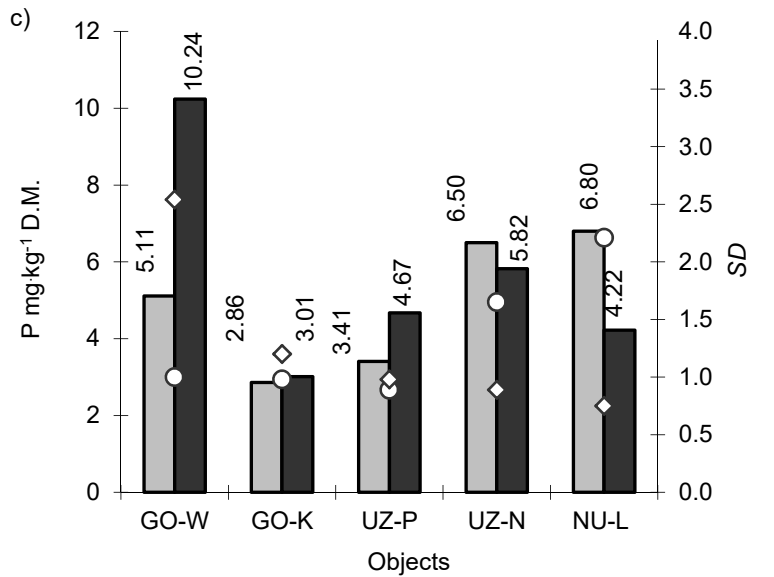

口اll-2017 Mean aX-2017 Mean Olll-2017 SD $\diamond X-2017$ SD tained tendency may indicate of the decomposition processes of crop residues from arable fields (Fig. 2).

The factor influencing to release of $\mathrm{P}$ and $\mathrm{N}$ from soil and migration of these nutrients to the soil-water environment is the mineralization process of soil organic matter. The process of soil mineralization of organic matter is the main cause of excessive release of these components to the soil solution, and the factors determining its pace is the change of redox conditions caused by the use of especially agrotechnical measures favouring oxygenation of soil [SAPEK 2010].

Losses of soil nitrogen after harvesting crops may pose a greater threat to the deterioration of water quality in the autumn and winter period, mainly during atmospheric precipitation, because the $\mathrm{NO}_{3}^{-}$anion is not subject to exchangeable sorption in the soil and is easily leached by rainwaters [CIEĆKO et al. 1996; JADCZYSZYN et al. 2010; VOS, MACKERRON 2000].

The total phosphorus $\left(\mathrm{P}_{\text {tot }}\right)$ content in the assessed soils from the Raszynka River valley occurred in a wide range of 0.33-4.00 mg $\mathrm{P}_{\text {tot }} \cdot \mathrm{kg}^{-1}$ D.M.). However, the most abundant in this nutrient was the soil taking from the natural meadow (2.40 $\mathrm{mg} \mathrm{P}_{\text {tot }} \cdot \mathrm{kg}^{-1}$ D.M.) and the alder forest (1.18 mg $P_{\text {tot }} \cdot \mathrm{kg}^{-1}$ D.M.) - Table 3 .

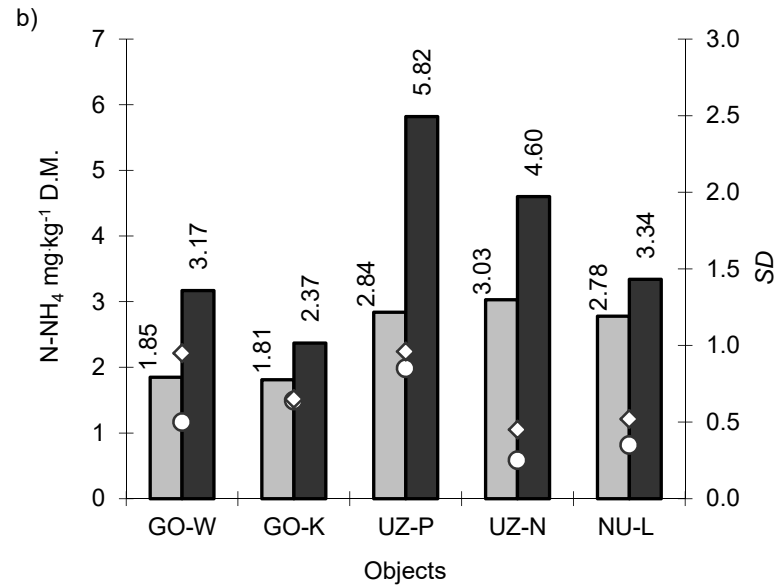

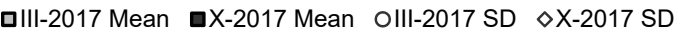

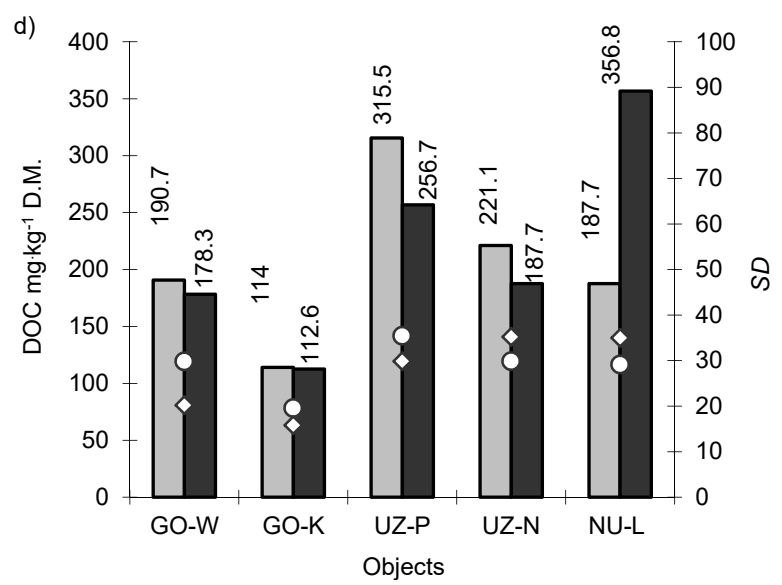

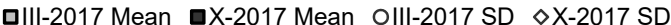

Fig. 2. The content of selected fertilizer nutrients in a soil layer up to $20 \mathrm{~cm}$ deep on the agricultural lands located in the vicinity of the Raszynka River: a) $\mathrm{N}^{-\mathrm{NO}_{3}}$, b) $\mathrm{N}_{-} \mathrm{NH}_{4}$, c) $\mathrm{P}$, d) DOC; source: own study 
The content of dissolved $\mathrm{P}$ forms was the highest in autumn after harvesting of ground vegetables from the arable land located in the river valley (GO-W: $10.24 \mathrm{mg}$ $\mathrm{P}_{\text {tot }} \cdot \mathrm{kg}^{-1}$ D.M.). The smallest of this nutrient content in soil, regardless of the time of sampling, was recorded in tons soils under long-term of the maize cultivation (GO-K: 2.86 $\mathrm{mg} \mathrm{P}_{\text {tot }} \cdot \mathrm{kg}^{-1}$ D.M.) - Figure 2. Small contents of some nutrients in the soil under maize cultivation may indicate a significant of the soil depletion, because the maize is a plant with high nutritional needs.

The dissolved $\mathrm{P}$ content in soil from natural meadows and from alder forest were slightly larger in spring $(<7.00$ $\mathrm{mg} \mathrm{P} \cdot \mathrm{kg}^{-1}$ in D.M.) than in autumn $\left(<5.00 \mathrm{mg} \mathrm{P} \cdot \mathrm{kg}^{-1}\right.$ in D.M.) - Figure 2.

Phosphates are compounds which are strongly connected by soil colloids because insoluble salts are formed during the reaction between phosphorus soluble from phosphate fertilizers and aluminum, iron and calcium ions. These salts considerably limit the availability of phosphorus for plants (phosphorus backflow) [FOTYMA et al. 1987; GŁODOWSKA, GAŁĄZKA 2018].

Dissolved phosphorus in the soil solution is accumulated in the largest amount in the top soil and may to migrate with the surface runoff and increase the risk of the surface water eutrophication. Even a small concentration of this component in the waters is considered dangerous for water quality [GORLACH, GAMBUŚ 1997; HOODA et al. 1999].

Similar studies on the land use methods of $\mathrm{N}_{\text {tot }}, \mathrm{P}_{\text {tot }}$, $\mathrm{BZT}_{5}$ concentrations in the surface waters, in Asia (Korea) were run by LEE et al. [2009]. These authors showed that the relationship between the studied parameters is influenced by crop types, irrigation and drainage systems and environmental conditions, i.e. precipitation, soil type and temperature.

In addition, it has been shown that the probability of deterioration of surface water quality is higher when there is a large diversity of land use in the catchment.

Most of the risks of surface water pollution in Poland are related to the structure of agricultural land use, and in particular the significant predominance of arable land $(60 \%)$ over grassland. The trend obtained is the largest indicator in the EU [JANKOWSKA-HUFLEJT 2006; ZBIERSKA (ed.) 2002].

Is estimated that permanent grassland in Poland accounts for only $21 \%$ of agricultural lands and $13 \%$ of the entire country [JANKOWSKA-HUFLEJT 2006]. According to RYSZKOWSKI et al. [2003], a strip of meadows with a width of 8 to $10 \mathrm{~m}$ can remove 64 to $97 \%$ (on average $90 \%$ ) of nitrates permeating the root system into waters. The excess of nitrates probably accumulates in the form of organic nitrogen in the root zone and is therefore not leached out constituting a geochemical barrier. In order to limit the risk of contamination of surface water with fertilizer components in agricultural catchments, and especially in river valleys, monitoring of the contamination of the cultivated soil and water layer should be carried out.

\section{CONCLUSIONS}

1. The Raszynka River waters were of low quality due to the high concentration of nitrogen, phosphorus and electrical conductivity $(E C)$. The most polluted of surface waters of the lower section of the river located in the vicinity of arable land and agricultural built-up areas, and the least water from the upper part of the river in the vicinity of the natural meadows.

2. The soluble forms of nutrients content in the cultivated soil layer were varied and depending on the kind of nutrient, way of agricultural land use, and the term of soil sampling.

3. The total organic carbon content in the soils of agricultural land in the vicinity of the Raszynka River varied (11.4-145 $\mathrm{g}$ TOC $\left.\cdot \mathrm{kg}^{-1}\right)$. Much more abundant of TOC and total dissolved forms of $\mathrm{N}$ and $\mathrm{P}$ were the meadow soil, especially of natural meadows (UZ-N) and from the alder forest than from the arable land, especially under growing maize (GO-K).

4. The organic matter content in the meadow soils stabilized of dissolved $\mathrm{N}$ and $\mathrm{P}$ forms release and constituted a geochemical barrier limiting the pollution of the lower part of the river.

5. The nitrogen and phosphorus content in the soils from the arable land was small, except for fields after autumn harvest of the ground vegetables. However, the concentration of these nutrients in the river's waters frequently exceeded the acceptable concentration range for the surface waters.

6. Dissolved P forms content in the soil was the highest in autumn on arable lands after harvesting of vegetables (GO-W: $10.24 \mathrm{mg} \mathrm{P}_{\text {tot }} \cdot \mathrm{kg}^{-1}$ in D.M.). This nutrient may migrate with the surface runoff and to increase the risk of surface water eutrophication.

7. In order to limit the effects of uncontrolled spreading of nutrients to the environment, periodic monitoring of the cultivated soil layer and surface water in river valleys in agricultural areas should be carried out.

\section{REFERENCES}

BURZYNSKA I. 2015. Zmiany stężeń fosforanów w wodach rolniczej zlewni rzeki Raszynki [The dynamic of phosphate concentration in surface waters of agricultural catchment area Raszynka River]. Polish Journal of Agronomy. No. 23 p. 24 30.

BURZYŃSKA I. 2016. Ocena wybranych wskaźników fizykochemicznych w wodach rzeki Raszynki [Evaluation on selected physical and chemical indicators in Raszynka River]. WodaŚrodowisko-Obszary Wiejskie. T. 16. Z. 3(55) p. 23-34.

CiećKo Z., Wyszkowski M., SzagaŁa J. 1996. Efekt 4-letniego nawożenia mineralnego azotem na zawartość $\mathrm{N}-\mathrm{NO}_{3}$ i N-NH $\mathrm{w}$ glebie [The effect of 4-year use of mineral nitrogen fertilizers on the content of $\mathrm{NO}_{3}-\mathrm{N}$ and $\mathrm{NH}_{4}-\mathrm{N}$ in soils]. Zeszyty Problemowe Postępów Nauk Rolniczych. Z. 440 p. 27-33.

Czarnecka B. (ed.) 2005. Atlas podziału hydrograficznego Polski. Cz. 2. Zestawienia zlewni [Atlas of the hydrological division of Poland. Vol. 2. Catchment list]. Warszawa. IMGW. Ser. Atlas. ISBN 8388897667 pp. 562. 
DoDDS W.Z. 2007. Trophic state, eutrophication and nutrient criteria in streams. Trends in Ecology and Evolution. Vol. 22 p. 669-676.

Hermanowicz W., Dojlido J., DożańsKa W., Koziorowski B., ZERBE J. 1999. Fizyczno-chemiczne badanie wody i ścieków [Physico-chemical study of the water and wastewater]. Warszawa. Arkady. ISBN 83-213-4067-9 pp. 558.

DąBKowski Sz.L., Pawłat-ZawrzyKraj A. 2003. Jakość wód Raszynki i jej dopływów [Water quality of the Raszynka River and its tributaries]. Woda-Środowisko-Obszary Wiejskie. T. 3. Z. specj. 6 p. 111-123.

Fotyma M., Mercik S., Faber A. 1987. Chemiczne podstawy żyzności gleb i nawożenia [Chemical basis for soil fertility and fertilization]. Warszawa. PWRiL. ISBN 83-09-00262-9 pp. 319 .

GAŁCZYŃSKA M., BuŚKO M. 2016. Stan zbiorników wodnych w Polsce oraz potencjalne i stosowane metody ich ochrony i rekultywacji [The state of water reservoirs in Poland and potential and used methods fot their protection and recultivation]. Wiadomości Melioracyjne i Łąkarskie. Nr 3 p. 140143.

GARG J., GARG H.K. 2002. Nutrient loading and its consequences in a lake ecosystem. Tropical Ecology. No. 43 p. 355-358.

GŁodOWSKA M., GAŁĄZKA A. 2018. Intensyfikacja rolnictwa a środowisko naturalne [Unsustainable agriculture and its environmental consequences]. Zeszyty Problemowe Postępów Nauk Rolniczych. Z. 592 p. 3-13.

Gorlach E., GAMBUŚ F. 1997. Nawozy fosforowe i wieloskładnikowe jako źródło zanieczyszczenia gleby metalami ciężkimi. [Phosphate and multi-ingredient fertilizers as a source of soil contamination with heavy metals]. Zeszyty Problemowe Postępów Nauk Rolniczych. Z. 448 p. 139-146.

Hooda P.S., Moynagh M., Svoboda I.F., Edwards A.C., ANDERSON H.A., Sym G. 1999. Phosphorus loss in drain flow from intensively managed grass-land soils. Journal of Environmental Quality. No. 28 p. 1235-1242.

IGRAS J., PASTUSZAK M. (ed.) 2009. Udział polskiego rolnictwa w emisji związków azotu i fosforu do Bałtyku [Contribution of Polish agriculture to emission of nitrogen and phosphorus compounds to the Baltic Sea]. Puławy. IUNG-PIB pp. 416.

JAdCZYSZYN T., PIETRUCH C., LiPIŃSKI W. 2010. Monitoring zawartości azotu mineralnego $\mathrm{w}$ glebach Polski w latach 2007-2009 [The monitoring of mineral nitrogen content in Polish soils in 2007-2010]. Nawozy i Nawożenie. Nr 38 p. 84-110.

JANKOWSKA-HuFLEJT H. 2006. The function of permanent grasslands in water resources protection. Journal of Water and Land Development. No. 10 p. 55-65. DOI 10.2478/ v10025007-0005-7.

Jeppesen E., Moss B., Bennion H., Carvalho L., DeMeester L., Feuchtmayr H., Friberg N., GesSner M.O., Hefting M., LAURIDSEN T.L., LiboriusSen L., MalmQUist H.J., May L., MeErhoff M., Olafsson J.S., SOONS M.B., Verhoeven J.T.A. 2010. Interaction of climate change and eutropication. In: Climate change impacts on freshwater ecosystems: Direct effects and interactions with other stresses. Eds. M. Kernan, B. Moss, R. Battarbee. Blackwell Publishing Ltd. p. 119-151.

Lee S.-W., Hwang S.-J., LeE S.-B., Hwang H.-S., SuNG H.-CH. 2009. Landscape ecological approach to the relationships of land use patterns in watersheds to water quality characteristics. Landscape and Urban Planning. Vol. 92 p. 80-89. DOI 10.1016/j.landurbplan.2009.02.008

LiU Y., Villalba G., Ayres R.U., Schroder H., 2008. Global phosphorus flows and environmental impacts from a consumption perspective. Journal of Industrial Ecology. Vol. 12. Iss. 2 p. $229-247$.
MarcineK J., KomisareK J. (ed.) 2011. Systematyka gleb Polski [Systematics of Polish soils]. Roczniki Gleboznawcze. T. 62. Nr 3 pp. 171.

Mooij W.M., Hülsmann S., De Senerpont Domis L.N., Nolet B.A., Bodelier P.L.E., Boers P.C.M., Dionisio Pires L.M., Gons H.J., Ibelings B.W., Noordhuis R., Portielje R., WOLFSTEIN K., LAMMENS E.H.R.R. 2005. The impact of climate change on lakes in the Netherlands: A review. Aquatic Ecology. No. 39 p. 381-400. DOI 10.1007/s10452005-9008-0.

PAWŁAT-ZAWRZYKRAJ A. 2003. Inwentaryzacja i waloryzacja przyrodniczo-krajobrazowa górnego biegu rzeki Raszynka [Ecological and landscape inventory and evaluation of the upper course of the Raszynka River]. Woda-ŚrodowiskoObszary Wiejskie. T. 3. Z. specj. 6 p. 97-110.

PB/31/02/2014 Procedura badawcza. Mineralizacja próbek gleby w ciekłej fazie z zastosowaniem stężonych kwasów mineralnych [Research procedure. Mineralisation of soil samples in a liquid phase using of concentrated mineral acids].

PB/31/03/2014. Oznaczanie całkowitego azotu w glebie za pomocą zmodyfikowanej metody Kiejdahl [Determination of total nitrogen in soil according to the modified Kjeldahl method] pp. 3.

PN-EN 1484:1999. Analiza wody. Wytyczne oznaczania ogólnego węgla organicznego (OWO) i rozpuszczonego węgla organicznego (RWO) [Water analysis. Guidelines for determination of total organic carbon (TOC) and dissolved organic carbon].

PN-EN 13652:2002. Środki poprawiające glebę i podłoża uprawowe. Ekstrakcja składników pokarmowych i pierwiastków rozpuszczalnych w wodzie [Soil improvers and growing media. Extraction of water soluble nutrients and elements].

PN-EN 25667-2:1999. Jakość wody. Pobieranie próbek. Wytyczne dotyczące technik pobierania próbek [Water quality. Sampling. Guidance on sampling technique].

PN-EN 27888:1999. Jakość wody. Oznaczanie przewodności elektrycznej [Water quality. Determination of electrical conductivity].

PN-EN ISO 6878:2006. Jakość wody. Oznaczanie fosforu. Metoda spektrofotometryczna z molibdenianem amonu [Water quality. Determination of phosphorus. Ammonium molybdene spectrometric metod].

PN-EN ISO 10390:1997. Jakość gleby. Oznaczanie pH [Soil quality. Determination $\mathrm{pH}]$.

PN-EN ISO 10523:2012 Jakość wody. Oznaczanie pH [Water quality. Determination $\mathrm{pH}]$.

PN-EN ISO 13395:2001. Jakość wody. Oznaczanie azotu azotynowego i azotanowego oraz ich sumy metodą analizy przepływowej (CFA i FIA) z detekcją spektrofotometryczną [Water quality. Determination of nitrite nitrogen and nitrate nitrogen and the sum of both by flow analysis (CFA and FIA) and spectrometric detection].

PN-ISO 9964-2:/Ak:1997 Jakość wody. Oznaczanie potasu w ściekach metodą atomowej spektrometrii atomowej [Water quality. Determination of potassium in waste by atomic absorption spectrometry].

PriJONO S.M., IDIYANINGRUM R.N., AFRIESA S. 2015. Infiltration and evaporation rate in different landscape in the Bango Watershed. Malang District. Indonesia. International Journal of Agriculture and Research. Vol. 3. Iss. 4 p. 1061-1067.

Rozporządzenie Ministra Środowiska z dnia 21 lipca 2016 w sprawie sposobu klasyfikacji stanu jednolitego części wód powierzchniowych oraz środowiskowych norm jakości dla substancji priorytetowych [Ordinance of the Environmental Minister of July 21, 2016 on the method of classification the state a uniform the surface water and environmental quality standards for priority substances]. Dz. U. RP. 2016 poz. 1187. 
RyszKowski L., BAŁAZY S., KęDZIORA A. 2003. Zarzadzanie i ochrona zasobów wodnych na obszarach wiejskich [Management and protection of water resources in rural areas]. Poznań. ZBŚRiL. PAN pp. 70.

SAPEK A., SAPEK B. 1997. Metody analizy chemicznej gleb organicznych [Methods of chemical analysis of organic soils]. Materiały Instruktażowe. Nr 115. Falenty. IMUZ. ISBN 8385735-66-6 pp. 80.

SAPEK B. 2010. Uwalnianie azotu i fosforu $\mathrm{z}$ materii organicznej gleby [Nitrogen and phosphorus release from soil organic matter]. Woda-Środowisko-Obszary Wiejskie. T. 10. Z. 3(31) p. $229-256$.

SAVCI S. 2012. An agricultural pollutant: Chemical fertilizer. International Journal of Environmental Science and Development. Vol. 3. No. 1 p. 77-80.

Suryoputro N., Suhardjono, Soetopo W., Suhartanto E.S., LiMANTARA L.M. 2018. Evaluation of infiltration models for mineral soils with different land uses in the tropics. Journal of Water and Land Development. No. 37 (IV-VI) p. 153-160. DOI 10.2478/wld-2018-0034.

Vos J., MACKeRron D.K.L. 2000. Basic concepts of the management of supply of nitrogen and water in potato production. In: Management of nitrogen and water in potato production.
Eds. A.J. Haverkort, D.K.L. Mackerron. Wageningen. Wageningen Academic Publ. p. 138-154.

WWAP 2009. Water in a changing world. The United Nations Water Development. Report 3. Paris, London. UNECSO, Earthscan. ISBN 978-92-3-104095-5 pp. 318.

Zak D., Kronvang B., Carstensen M.V., Hoffman C.C., KJeldgaArd A., Larsen S.R., Audet J., Egemose S., Jorgensen C.A., Feurbach P., Gertz F., Henning S., Jensen H. 2018. Nitrogen and phosphorus removal from agricultural runoff in integrated budffer zones. Environmental Science and Technology. Vol. 52. Iss. 11 p. 6508-6517. DOI 10.1021/acs.est.8b01036.

ZBIERSKA J. (ed.) 2002. Bilans biogenów w agrosystemach Wielkopolski w aspekcie jakości wody na przykładzie zlewni Samica Stęszewska [Biogen balance in the Wielkopolska agrosystems in the aspect of water quality on the example of the catchment Samica Stęszewska]. Poznań. AR pp. 133.

ZBYTeK Z., TALARCZYK W. 2012. Sposoby ograniczania negatywnego oddziaływania agregatów ciągnikowych na glebę [Ways to limiting the negative impact of traktor aggregates on the soil]. Problemy Inżynierii Rolniczej. Nr 4(78) p. 5768 .

\section{Irena BURZYŃSKA}

\section{Monitoring skladników nawozowych w wodach powierzchniowych i glebach użytkowanych rolniczo w dolinie rzecznej}

\section{STRESZCZENIE}

Celem pracy była ocena zawartości rozpuszczalnych form składników nawozowych (N, P, K) w uprawnej warstwie gleby do $20 \mathrm{~cm}$ głębokości na gruntach rolniczych w dolinie rzecznej oraz stężenia tych składników w wodach powierzchniowych rzeki Raszynki.

W latach 2016-2017 do badań pobierano próbki wód powierzchniowych z rzeki (17 punktów) i gleby (19 punktów) $\mathrm{z}$ terenów rolniczych sąsiadujących z rzeką Raszynką. Próbki wód powierzchniowych pobierano raz w miesiącu w okresie III-X 2016-2017. W roztworach wodnym i po ekstrakcji gleby oznaczono zawartość związków azotu $\left(\mathrm{N}_{\mathrm{og}}, \mathrm{N}^{-\mathrm{NO}_{3}}\right.$ i N-NH 4 ), fosforu $\left(\mathrm{P}_{\mathrm{og}}, \mathrm{P}-\mathrm{PO}_{4}\right)$, ogólnego węgla organicznego - OWO (ang. total organic carbon - TOC) oraz K i Ca. Wykazano, że wody rzeki były niskiej jakości ze względu na znaczne stężenie azotu i fosforu oraz wartości przewodności elektrycznej właściwej $(E C)$. Najbardziej zanieczyszczone były wody dolnego odcinka rzeki położone w sąsiedztwie gruntów ornych oraz rolniczych terenów zabudowanych. Zawartość rozpuszczalnych form składników w uprawnej warstwie gleby była zróżnicowana w zależności od rodzaju składnika mineralnego, sposobu użytkowania gruntów rolnych oraz terminu pobrania próbek gleby.

Zawartość rozpuszczonych form $\mathrm{P} w$ glebie była największa jesienią na gruntach ornych po zbiorze warzyw (GO-W: $10.24 \mathrm{mg} \mathrm{P} \mathrm{og}_{\mathrm{og}} \cdot \mathrm{kg}^{-1}$ s.m.), a składnik ten może migrować ze spływem powierzchniowym i zwiększać ryzyko eutrofizacji wód powierzchniowych.

Słowa kluczowe: dolina rzeczna, sktadniki biogenne, uprawna warstwa gleby, wody powierzchniowe, zlewnia rolnicza 